\title{
Spanish is not spoken here!
}

\author{
Lourdes Torres ${ }^{1}$
}

Published online: 18 January 2019

(C) Springer Nature Limited 2019

I am sure you have seen or heard about some of the acts of linguistic prejudice spotlighted recently in the news and on social media. Sometimes this feels like it is a new trend. But is it? The incident that has received the most attention is the case of a white lawyer, Aaron Schlossberg, filmed on May 2018, yelling at the employees of a restaurant in Manhattan for speaking Spanish to customers. He goes on to bark at their supervisor, "My guess is they're not documented, so my next call is to ICE to have each one of them kicked out of my country. ... They have the balls to come here and live off of my money? I pay for their welfare; I pay for their ability to be here. The least they could do, the least they could do is speak English" (https:// thehill.com/homenews/news/388837-lawyer-who-threatened-to-call-ice-on-spanishspeaking-people-i-am-not-racist).

Incidents like this appear on social media almost weekly, and the most vile cases make it to local and national news. A few months ago, in a restaurant in Virginia, a white woman accosted a family speaking in Spanish as they dined. She yelled, "Speak English!" and demanded to see their passports. She was eventually escorted out of the restaurant, as she screamed, "Go back to your fucking country, OK? Don't freeload on America" (https://www.dailydot.com/irl/virginia-woman-harassingspanish-speakers/).

More recently, in a Colorado grocery store, a white woman harassed two Mexican women for speaking Spanish to each other while they were shopping. She yelled, "You're in America. You're in my country. You can't speak Spanish here. You need to speak English if you're going to be in America" (https://www.washingtonpost. com/nation/2018/10/04/get-out-woman-roars-defense-spanish-speakers-confronted -not-speaking-english/?noredirect=on\&utm_term=.30f74a2d1576).

Lourdes Torres

1torres@depaul.edu

1 DePaul University, Chicago, USA 
In each of these cases, someone filmed the racist rant and put it on social media, where these videos went viral, shaming the harassers. In the Colorado case at the supermarket, another white woman interrupted the verbal assault and called the police. In the situation in the restaurant in Virginia, the harassing white woman was banned from the restaurant. Aaron Schlossberg was hounded relentlessly on social media, the landlord of his Manhattan law office cancelled his lease, and for three days angry protesters gathered outside his home. On the last day of protest, about five hundred people showed up outside his apartment building waving flags from Latin American countries as five-piece mariachi band played "La Cucaracha" (https://abc7ny.com/society/mariachi-band-protests-outsi de-apartment-of-lawyer-caught-in-racist-video/3493326/).

We can debate whether or not instances like this are more common now because of the current administration, or whether social media has merely amplified such incidents of linguistic profiling, but it is undeniable that prejudice and attacks against languages other than English have a long history in the United States.

Language politics have always been contentious in the US, and the volume gets turned up during periods of political or economic unease, when immigrants are targeted as a threat to the nation. Other languages have coexisted with English since the founding of the nation, and although the US does not have a federal official language policy, it is indisputable that English is dominant, the language of power. Nativists, nonetheless, tend to insist on the equation of speaking English with Americanness and oppose other languages in public or even in private spaces.

The asymmetric relationship between English and Spanish in the United States is rooted in imperialism, colonialism, white supremacy, and fear of immigration from Latin America. But its history has also been mixed, with vacillating and sometimes coterminous periods of both tolerance and repression.

In the 1960s and 1970s, language rights emerged as a civil rights issue, resulting in gains in the areas of education and translation of voting materials. Since the 1980s and 1990s, we have witnessed a backlash to these advancements with the proliferation of English-only laws; currently 32 states have declared English their official language and bilingual education programs have been gutted across the country.

But again, even in times of backlash, we see contrary trends. For example, although we are currently living through another period of nativist exuberance, bilingual education was reinstated in California in 2016. Proposition 58 was approved by voters with a $73.5 \%$ majority. And just last year, Massachusetts passed a bipartisan bill that allows local schools to tailor bilingual programs for students who are not fluent in English.

Also, across the nation, as we are witnessing these ugly linguistic-profiling cases, we are also seeing growing support for dual-language programs. Dual-language programs - in which students learn core subject matter in two languages - are increasing in popularity. In 2000, there were about 260 dual-language programs in the US; by 2011 , there were 2,000 (http://hepg.org/hel-home/issues/27_2/helarticle/duallanguage-programs-on-the-rise). Communities are embracing dual-language immersion programs because of the recognized economic, cognitive, and academic benefits of bilingualism. 
Unfortunately, we cannot assume that change will occur just because researchers share their expertise with the wider public and explain, for example, that Spanish has a long history in the US, that all language varieties have legitimacy, or that bilingualism promotes cognitive and intellectual advantages.

Zentella (2002, 2014), Rosa and Flores (2015, 2017), and other scholars have demonstrated that although race and language are typically treated as separate objects of inquiry, it is impossible to talk about one without the other, since race and language are mutually constituted. So, we need to examine the co-construction of language and race, the role that language ideologies play in establishing racial difference, and the role of racialization in the production of linguistic difference.

As these videos demonstrate, in many places in the US today, Spanish-language use is perceived as an insult and affront to Americanism. With their rants, these people are saying that Spanish does not have a legitimate place in restaurants and stores, even in private conversations. Spanish doesn't belong, and by extension, people who speak this language should not be here. Language acts as a sign of place and legitimacy. And, for Latinos, our language practices, as well as our bodies, are criminalized and forever connected with illegality.

Make no mistake, the criticism hurled at Latinos for speaking Spanish is not based simply on a perceived failure to adhere to monolingual American norms; it is predicated on the fact that the Spanish language emerges from racialized bodies and thus is heard as illegitimate by white supremacists. Historically, it has always been more acceptable to attack the linguistic behaviors of a group rather than the group itself, while clearly, as Gloria Anzaldúa reminds us, the attack on language practices is a veiled attack on the people who speak the language. Language and culture are especially fertile sites for the reproduction of racism. As we see in the examples above, hateful rants move very quickly from commentary on language to attacks on Latinos for being illegal, on welfare, etc., etc..

Language is always tied to issues of identity, history, and relations of power. Sociolinguists' attempts to correct mistaken beliefs about an English-only United States, or to promote the cognitive and intellectual benefits of bilingualism, will only go so far, since these "objective" historical and linguistic facts are often ignored, as is the broader sociohistorical context within which discourses of Latinos' perceived linguistic deficiencies have developed and continue to proliferate. Too narrow a focus on misconceptions about languages and linguistic practices misses the bigger picture. Scholars and activists must continue to speak out and confront racist attacks against Spanish, always within the larger context. Clearly, we have a lot of work to do-it will take a sustained effort to challenge white supremacist ideologies that devalue marginalized groups' ways of speaking and preserve prescribed norms.

¡Basta ya!

\section{References}

Flores, N., and J. Rosa. 2015. Undoing Appropriateness: Raciolinguistic Ideologies and Language Diversity in Education. Harvard Educational Review 85 (2): 149-171. 
Rosa, J., and N. Flores. 2017. Unsettling Race and Language: Toward a Raciolinguistic Perspective. Language in Society 46 (5): 621-647.

Zentella, A.C. 2002. Latin@ Languages and Identities. In Latinos: Remaking America, ed. Marcelo M. Suárez-Orozco and Mariela Páez, 321-338. Berkeley: University of California Press.

Zentella, A.C. 2014. TWB (Talking While Bilingual): Linguistic Profiling of Latina/os, and Other Linguistic Torquemadas. Latino Studies 12 (4): 620-635.

Publisher's Note Springer Nature remains neutral with regard to jurisdictional claims in published maps and institutional affiliations. 